\title{
Not dead yet: Diatom resting spores can survive in nature for several millennia.
}

Anushree Sanyal*1, ${ }^{*}$, Josefine Larsson ${ }^{1}$, Falkje van Wirdum ${ }^{1}$, Thomas Andrén ${ }^{1}$, Matthias Moros ${ }^{3}$, Mikael Lönn ${ }^{1}$, Elinor Andrén ${ }^{1}$.

5

${ }^{1}$ School of Natural Sciences, Technology and Environmental Studies.

Södertörn University, Alfred Nobels allé 7, SE-14189 Huddinge, Stockholm, Sweden.

${ }^{2}$ Present address: Department of Organismal Biology, Systematic Biology, Norbyvägen 18D,

10 Uppsala University, SE-75236 Uppsala, Sweden.

3. Leibniz Institute for Baltic Sea Research Warnemünde, Seestraße 15, DE-18119 Rostock. Germany.

* Author for correspondence: Anushree Sanyal (email: anushree.sanyal@ebc.uu.se) Phone: +46184716471 
40

45

Keywords: Resurrection ecology, Diatom, Resting spores, Chaetoceros, Germination rate.

We show for the first time the revival, viability and germination rate of resting spores of the diatom Chaetoceros deposited in sub-seafloor sediments from three ages (recent: 0-80 years; ancient: $\sim 1300$ and $\sim 7200$ calendar year before present. Sanger sequences of nuclear and chloroplast markers were performed. Our findings showed that $\sim 7200$ calendar year BP old Chaetoceros resting spores are still viable and the physiological response pertaining to vegetative reproduction in recent and ancient resting spores vary. The time taken to germinate is three hours to 2-3 days in both recent and ancient spores but the germination rate (\%) of the ancient spores decrease with increasing time. Based on the morphology of the germinated vegetative cell we were able to identify the species as Chaetoceros muelleri.

Studies of revived resting spores of marine diatoms will serve as excellent proxies of environmental change in marine environments and enable us to reconstruct $\sim 7000$ years of diatom evolution in relation to changes of their environment. Comparison of resurrected populations obtained from these natural archives of diatoms can provide predictive models to forecast evolutionary responses of populations to environmental perturbations from natural and anthropogenic stressors, including climate change over longer timescales. 


\section{Introduction}

Human domination of the Earth's ecosystems has accelerated in recent decades, to the extent that this period has been termed as the Anthropocene (Waters et al. 2016). Phytoplankton forms the basis of the marine food web and hence if we understand how phytoplankton will respond to environmental and

80 climate change we will have a better chance to understand ecosystem change. Changes in species abundance with increased numbers of planktic, resistant, toxic, and introduced species due to nutrient enrichment and resulting symptoms of eutrophication, hypoxia, metal pollution and acidification (Yasuhara et al. 2012) has resulted in significant loss of biodiversity in the

85 marine environment. We have very little knowledge about how the Earth's biota will be affected both directly (Hofman et al. 2015) and evolutionary (Larsson et al. 2016; Whitehead 2014) by human-induced climate change, increased pollution and eutrophication. Understanding how the global biodiversity and their adaptive responses will be affected by anthropogenic

90 perturbations has emerged as a major challenge to humanity (Hofman et al. 2015; Schlüter et al. 2014). Our current inability to do so hampers our understanding of how the future ocean will function.

Resurrection ecologists have long recognized sediments as sources of viable

95 propagules ("seed or egg or resting spore banks") for studying ecological and evolutionary responses (Cáceres and Hairston 1998). Resting stages in the sediment are of ecological and paleoecological importance as they can be revived when exposed to suitable environmental conditions and used as a source of genetic material for microevolutionary studies (Ellegaard and Ribeiro

100 2017). Studies predicting how evolution will shape the genetic architecture of populations coping with present and future environmental challenges has primarily relied on investigations through space, in lieu of time. Yet, dormant propagules in sediments are natural archives from which adaptive trajectories of populations could be traced along extended time periods. Currently, only a

105 century old diatom resting spores have been revived (Härnström et al. 2011), and studies on dinoflagellates have shown that the survival periods of several marine dinoflagellate resting stages ranging from several months to 100 years (Miyazono et al. 2012). Previous studies on Daphnia and Sphagnum resurrected $\sim 700$ years old ancient eggs (ephippia) and spores (Yousey et al. 2018, Bu et 
110 al. 2017). Hence, we lack a model system to study the changes occurring over longer evolutionary timescales. A key to understanding the adaptive capacities of species over evolutionary time lies in examining the recent and millennia old resting spores buried in the sediments.

115 Resting spore formation in diatoms is an effective strategy to survive periods of stress and has enabled diatoms to withstand events of mass extinction during the end of Cretaceous period (Kitchell et al., 1986). Climate, nutrient concentration, anthropogenic disturbances and physical oceanographic conditions can influence the distribution, composition and abundance of diatom

120 species (Crosta et al. 1997) and render them a useful probe to study environment induced adaptations over long timescales (Orsini et al. 2013; Burge et al. 2017). Furthermore, DNA sequence data obtained from these natural archives of resurrected organisms, combined with the next generation DNA sequencing methods and models for analyzing both ecological and

125 population genomic data can help predict the evolutionary responses of natural populations to environmental changes resulting from natural and anthropogenic stressors, including climate change (Orsini et al. 2013).

Globally, Chaetoceros is an abundant and diverse marine planktic diatom 130 genus which plays a major role in marine primary production (Malviya et al. 2016). Studies in the Baltic Sea Area show that the present distribution of Chaetoceros species correlates with the salinity gradient resulting in higher diversity in the more marine Kattegatt and Danish straits and lower diversity in the brackish central Baltic Proper and in the nearly freshwater Bothnian Bay

135 (Andersen et al. 2017; Fig. 1). Due to its dissolution-resistance and a high sedimentation rate (which would result in quick burial of the spores) in the Baltic basin, Chaetoceros resting spores are found throughout the sediment stratigraphy from when marine water entered the Baltic proper (named the Littorina Sea, 7500 years ago) till date (Andrén et al. 2000; Witak et al., 140 2011).

The Baltic Sea ecosystem has strong horizontal (salinity, temperature) and vertical (also oxygen) environmental gradients (Snoeijs-Leijonmalm and Andrén, 2017). The vertical salinity gradient results in stratification which 
145 together with ongoing eutrophication causes large areas with hypoxic and anoxic (oxygen concentration $<2$ and $<0 \mathrm{mg} \mathrm{L-1}$ ) bottom waters (Carstensen et al. 2014). The Littorina Sea ( 7500-3000 cal yr before present (BP)) reached a maximum surface water salinity of 12-13 in the Baltic Proper, compared to present day 5-7.5 (Gustafsson and Westman 2002). The higher salinity

150 coincides with the Holocene Thermal Maximum (HTM), with warm and dry climate dated to $\sim 8000-5000$ cal yr BP (Seppä et al. 2009). Also, postdeglaciation of Scandinavia, interactions between global sea level rise and isostatic adjustments resulted in different freshwater and brackish water stages, during a geologically and evolutionarily short period of time (Andrén et

155 al. 2011; Snoeijs-Leijonmalm and Andrén, 2017).

In the open Baltic Proper, high Chaetoceros resting spore abundances are found in the laminated, hypoxic sediments deposited during three time periods: the last century, the Medieval Climate Anomaly (MCA, 1000-700 cal yr BP,

160 Mann et al. 2009) and the HTM (Andrén et al. 2000). The abundances of resting spores in sediments from the Baltic Basin are attributed to high primary production and eutrophication (Andrén et al. 1999; 2000) and also coincides with high temperatures and higher surface water salinities (Zillén et al. 2008), at least during the HTM.

To systematically study the effects of anthropogenic perturbations over long time scales we need (1) a model organism whose resting spores have accumulated over a long period of time and (2) its ecosystem where the deposited resting spores have been subjected to anthropogenic perturbations over long timescales. The overall objective of the present study is to determine if Chaetoceros resting spores preserved in Baltic Sea sediments is a good model system to study the impact of anthropogenic perturbations over long time scales. The specific aims are to examine if the resting spores from three ages (recent, MCA and HTM) can be (i) revived by germinating them (ii) DNA

175 extracted, amplified and sequenced, and (iii) identified to species level (since many spores have identical morphology in comparison to germinated living cells). In this study we identify and present a unique model system, Chaetoceros resting spores from the Baltic Sea, which will help understand the effects of anthropogenic alterations on the evolutionary fate of natural 
180 populations on an evolutionarily significant temporal scale instead of spatial scale.

\section{Materials and Methods}

\section{Sampling}

185 The Integrated Ocean Drilling Program (IODP) Expedition 347 drilled the Baltic Proper from R/V Greatship Manisha during September to November 2013. The M0063 site (58 $\left.37.32^{\prime} \mathrm{N}, 18^{\circ} 15.24^{\prime} \mathrm{E}\right)$ in the Landsort Deep, the deepest part of the Baltic Proper at a water depth of $437 \mathrm{~m}$ was drilled during this expedition (Fig. 1). Five holes (M0063A to M0063E) were drilled, using an advanced piston

190 corer with perfluorocarbon added in the liner fluid to trace possible contamination, down to a diamicton (till) was reached at about 92 meters composite depth (mcd) (Andrén et al. 2015). The sediments were stored in the dark in a cold room at $4^{\circ} \mathrm{C}$. All Expedition 347 cores were split and sub-sampled during the onshore science party at IODP Core Repository in Bremen, Germany,

195 January to February 2014. Sediment samples used for revival experiments were requested from holes C and D in March 2015 and sub-sampled by the curators at IODP Core Repository in Bremen. The drilling site was revisited in June of 2014 with M/S Fyrbyggaren and the topmost unconsolidated sediments were sampled with a 1-m gravity corer. Two cores $87 \mathrm{~cm}$ (named M0063H,

$200 \mathrm{~N} 58^{\circ} 37.34^{\prime}, \mathrm{E} 18^{\circ} 15.29^{\prime}$ ) and $63 \mathrm{~cm}$ (named M0063I, N58 ${ }^{\circ} 37.35^{\prime}, \mathrm{E} 18^{\circ} 15.25^{\prime}$ ) respectively were retrieved and immediately subsampled in 1 -cm slices and stored in the dark in a cold room at $4^{\circ} \mathrm{C}$.

\section{Lithology and sample selection}

205 The lithology at site M0063 is divided into seven lithostratigraphic units very briefly described as; below 92 mcd diamicton, 92 - 32 mcd laminated clays on $\mathrm{cm}$-scale which gradually change to mixed clays in the upper part, $32-26$ mcd homogeneous clays with sulphide banding, 26 - 0 mcd organic rich clays with more or less pronounced laminaes on mm-scale (Andrén et al. 2015).

Based on the results from the onshore science party (Andrén et al. 2015), samples from three sediment sections of different age with anticipated high spore abundance were selected to trace the genetic diversity and the evolutionary changes in the Chaetoceros populations: the last century (M0063I 
215 0-63 cm), MCA (M0063C 5.42-6.32 mcd) and the HTM (M0063D 21.63-26.05 mcd).

\section{Dating and age modelling}

The two old selected time intervals corresponding to the MCA (M0063C) and

220 the HTM (M0063D) were dated by radiocarbon accelerator mass spectrometry (AMS) at Beta Analytic, USA.

In order to assign a calendar year age to each level analyzed an age-depth modeling was performed using the software CLAM version 2.2 (Blaauw, 2010)

225 with 2000 iterations and a custom-built calibration curve based on the IntCal13 calibration dataset (Reimer et al. 2013) with a mean and standard deviation of 900 and $500{ }^{14} \mathrm{C}$ years respectively (Obrochta et al. 2017). The sediment surface is assumed to be modern (i.e. 2013, the year of the coring).

230 The youngest sediment (the two short gravity cores $\mathrm{M0063 \textrm {H }}$ and $\mathrm{M0063 \textrm {I }}$ ), was dated using stratigraphic time markers (Moros et al. 2017). In order to identify stratigraphic time markers, mercury $(\mathrm{Hg})$ and artificial radionuclide $\left({ }^{137} \mathrm{Cs}\right.$ and ${ }^{241} \mathrm{Am}$ ) measurements on $\mathrm{M0063 \textrm {H }}$ have been performed. Core correlation of $\mathrm{M0063 \textrm {H }}$ and $\mathrm{M0063 \textrm {l }}$ is based on characteristic features of the mercury

235 downcore profiles. $\mathrm{Hg}$ and ${ }^{137} \mathrm{Cs}$ were normalized to bulk organic carbon (TOC) in order to eliminate the dilution effect of the massively occurring manganesecarbonate layers.

\section{Resting spore concentration}

240 To calculate the concentration of resting spores in the upper $30 \mathrm{~m}$ (mcd) from hole M0063D, sediments were freeze-dried, and a known weight of sediment (on average $\sim 0.1 \mathrm{~g}$ ) was subsampled. Cleaning of diatoms were performed according to standard procedures (Battarbee 1986). Microspheres were added in the last step to allow for the calculation of resting spore concentrations 245 before mounting for permanent slides in Naphrax ${ }^{\mathrm{TM}}$ (Battarbee and Kneen 1982). A total of 54 samples were analyzed for diatom spores using light microscopy at 1000x magnification and immersion oil. Due to the difficulties in differentiating between the morphology of Chaetoceros resting spores, they were not separated to species level. Concentrations of Chaetoceros resting 
250 spores were calculated and expressed in numbers of valves per gram dry weight (gdw) (Battarbee and Kneen, 1982).

Single resting spore isolation from several millenia old resting spores.

Resting spores were isolated from recent sediment samples ( the last century)

255 as well as from MCA and HTM ages. The isolation procedure was modified from Throndsen (1978) were each sample was diluted with $\sim 1 \mathrm{ml}$ of sterile $\mathrm{ddH}_{2} \mathrm{O}$ in a $30 \mathrm{~mm} \times 15 \mathrm{~mm}$ petri dish and a drop of the solution was placed on a concave microscope slide. Individual resting spores were isolated through manual suction using 20-40 $\mu$ drawn-out disposable pipettes and examined on a

260 concave microscopic slide under an inverted microscope with a 10x objective and a WF40x eyepiece with a total magnification of 400x. The isolated resting spore possibly with associated contaminants was transferred to a new $\mathrm{ddH}_{2} \mathrm{O}$ water droplet. This isolation and transfer was repeated 2-5 times to remove any contaminants. Individual resting spores were then isolated for the final

265 time and transferred to a $30 \mathrm{~mm} \times 15 \mathrm{~mm}$ petri dish containing artificial seawater medium (Tropic marine ${ }^{\circledR}$ Wartenberg, Germany).

Germination and germination rate of the recent and several millenia old resting spores

270 The resting spores from the last century, MCA and HTM ages were germinated in $30 \mathrm{~mm} \times 15 \mathrm{~mm}$ petri dishes containing artificial seawater medium with salinities ranging from $\sim 10.5$ to $\sim 11$ at temperatures ranging between 15 to $18^{\circ} \mathrm{C}$.

275 The germination rates of the resting spores were estimated by counting the number of germinated spores that germinated in a field of the microscope. The germination rate observed in 12 to 21 microscopic fields were recorded for each sample at a total magnification of 400X. The average germination rate for the recent and ancient resting spores were calculated. The germination rate 280 was analyzed using a one-way ANOVA with the age of the resting spores as the fixed effect and the germination rate as the dependent variable using $\mathrm{R}$ ( $\mathrm{R}$ Core Team, 2017). 


\section{Growing the unialgal Chaetoceros cultures}

Unialgal cultures of Chaetoceros from revived individual resting spores from the last century were established from an inoculum from the petri dish which was transferred to a $50 \mathrm{ml}$ angled neck Nunc ${ }^{\circledR}$ EasY Flasks ${ }^{\mathrm{Tm}}$ with vent caps. The flasks were filled with the Guillard's (F/2) Marine Water Enrichment Solution 290 which contained silicate and grown in growth chambers with controlled temperature $\left(15-18^{\circ} \mathrm{C}\right)$ and a $12: 12$ light-dark regime. The culture media was prepared by adding $20 \mathrm{ml}$ of the Guillard's F/2 medium in $1 \mathrm{~L}$ of artificial

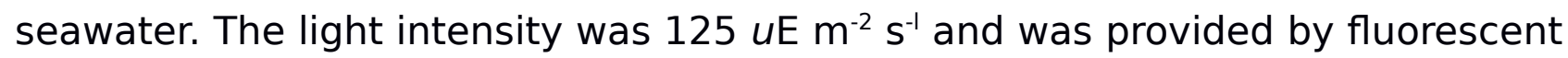
lamps. The cultures were subcultured every two weeks to maintain the culture.

\section{Identification of the Chaetoceros species}

The germinated Chaetoceros species was cleaned in hydrogen peroxide according to the method described in Battarbee (1986), dried onto a coverslip and mounted in Naphrax ${ }^{\mathrm{TM}}$ (refraction index $\mathrm{n}_{\mathrm{D}}=1.73$ ). Qualitative analysis was

300 carried out with an Olympus BX51 light microscope using Nomarski differential interference contrast with a magnification of 1000x and oil immersion. Diatom species identification followed Cleve-Euler (1951), Ishii et al. (2011), Johansen and Rushforth (1985) and Krammer and Lange-Bertalot (1991).

305 DNA isolation from diatom cultures of recent resting spores

Total DNA was extracted from each Chaetoceros culture (based on revived spores from the last century) as described below. $25 \mathrm{ml}$ of the cell cultures were centrifuged at $2500 \mathrm{rpm}$ for $10 \mathrm{~min}$ in a $50 \mathrm{ml}$ Falcon tube, $20 \mathrm{ml}$ of the supernatant was discarded using a syringe. The remaining $5 \mathrm{ml}$ were 310 centrifuged again at $2500 \mathrm{rpm}$ for $5 \mathrm{~min}$. $4 \mathrm{ml}$ of the supernatant was discarded. The remaining $1 \mathrm{ml}$ was spun for 2 minutes. The supernatant was discarded. Genomic DNA was extracted using a modified chloroform method with the addition of cetyltrimethylammonium bromide (CTAB) as describe by Zuccarello and Lokhorst (2005). The culture pellet was grinded with microfuge 315 pestle in $500 \mu \mathrm{l}$ of CTAB extraction buffer ( $2 \%$ CTAB, 0.1 Tris- $\mathrm{HCl}(\mathrm{pH} 8.0), 1.4 \mathrm{M}$ $\mathrm{NaCl}, 20 \mathrm{mM}$ EDTA, 1\% PVP), $2 \mu \mathrm{l}$ RNAse A $(100 \mathrm{mg} / \mathrm{ml})$ and $5 \mu$ Proteinase $\mathrm{K}$ $\left(20 \mathrm{mg} / \mathrm{ml}\right.$ ) and the tubes were incubated at $55-60^{\circ} \mathrm{C}$ for $30 \mathrm{~min}$. Equal volume of chloroform:isoamyl alcohol (24:1) was added and mixed. The tubes were 
then spun at $12,000 \mathrm{~g}$ for 5-10 $\mathrm{min}$. The supernatant was removed to a new

320 tube, avoiding interface. This step was repeated. DNA was precipitated in $100 \%$ ice-cold isopropanol, each tube was inverted and placed at room temperature for $30 \mathrm{~min}$. The tubes were spun for $20 \mathrm{~min}$ at $12,000 \mathrm{~g}$. The DNA pellet was washed in $500 \mu \mathrm{l}$ of $70 \%$ ethanol and the tubes were spun for $5 \mathrm{~min}$. The supernatant was poured out and the DNA pellet was air-dried. The DNA pellet

325 was suspended in $50 \mu$ of $0.1 \times(0.1 \mathrm{mM}$ EDTA, $1 \mathrm{mM}$ Tris $)$ TE buffer. The quality of the DNA extraction was assessed by visualizing the products on a $1.5 \%$ agarose gel and the DNA concentration was evaluated with a nanodrop. The DNA was then frozen at $-80^{\circ} \mathrm{C}$ for subsequent PCR and sequencing reactions.

330 DNA isolation from single millenia old Chaetoceros resting spores Single cell Chelex ${ }^{\circledR}$ DNA extraction was performed on spores which were obtained from the sediments of MCA age by using the Chelex method. For DNA extraction, Chelex-stored samples were incubated for $20 \mathrm{~min}$ at $95^{\circ} \mathrm{C}$. They were then vortexed for $15 \mathrm{~s}$ and centrifuged for $15 \mathrm{~s}$ at $12,000 \mathrm{~g}$. DNA 335 extraction from the germinated resting spores of the HTM age will be done in a future study.

\section{PCR and sequencing}

For the PCR reaction, $25 \mu \mathrm{L}$ of reaction mixture contained as a final 340 concentration, the two primers at 15 pmole each; 5-20 ng DNA template; 0.2 mM each dATP, dCTP, dGTP and dTTP; $2.5 \mu \mathrm{L}$ of 10×PCR buffer for Blend Taq (25 mM MgCl 2 concentration); and 0.1 units of Blend Taq polymerase (Thermo Scientific). The PCR condition was as follows: an initial step at $94^{\circ} \mathrm{C}$ for 2 min followed by 30 cycles with a denaturation temperature of $94^{\circ} \mathrm{C}$ for $30 \mathrm{~s}$, an

345 annealing temperature of $53^{\circ} \mathrm{C}$ for $30 \mathrm{~s}$ and an extension temperature of $72^{\circ} \mathrm{C}$ for $1.5 \mathrm{~min}$. The PCR was assessed by visualizing the products on $1.5 \%$ agarose gel. Six primer pairs from nuclear ribosomal RNA (SSU) and chloroplast DNA $(r b c L)$ from three unialgal cultures were amplified (Table 3). Sanger sequencing was performed on the PCR products (Macrogen inc.) of six nuclear ribosomal 350 RNA (small (SSU) and chloroplast DNA ( $r b c L$ ) markers which was used to amplify Chaetoceros species (Lee et al. 2013) (Table 3). 


\section{Analysis of DNA sequences}

355 The sequences were blasted using the nucleotide BLAST tool of NCBI. Sequences were aligned by using Molecular Evolutionary Genetics Analysis version 5 (MEGA5) (Table 3).

\section{Results}

360

\section{Dating and age modelling}

Two sediment samples of MCA age and four samples of HTM age were radiocarbon dated (Table 1 ) and used for age modelling to assign an age to all individual samples used for the resurrection study (Table 2). Radiocarbon

365 dating together with stratigraphic time markers for the youngest sediment (Fig. 3) showed that our samples were from three distinct time intervals from present time (0 years) to 7200 cal yr BP. The sediment from the short gravity core M0063I with an anticipated age of the last century could be assigned an age of ca. 1940-1935 (i.e. $\sim 0$ - 80 years) at $63 \mathrm{~cm}$, based on the stratigraphic

370 time markers identified (Fig. 3). The sediment samples used for the resurrection study gave after age modelling ages of $\sim 1300-1000$ cal yr BP from MCA age (M0063C 5.42-6.32 mcd) and 7200-6000 cal yr BP of HTM age (M0063D 21.63$26.05 \mathrm{mcd}$ ) (Table 2). Age modelling made it possible to estimate the calendar years age for all levels analyzed except for the sample at 6.32 mcd which was

375 outside the dated interval. A linear extrapolation from the sample at $6.22 \mathrm{mcd}$ was used to estimate the age of this sample (Table 2).

\section{Resting spore concentration across evolutionary timescales}

We reconstructed the Chaetoceros spp. resting spore concentrations and 380 observed that the highest concentration ( 203 million resting spores per gram dry weight of sediment at 26 mcd) in the sediments deposited during the HTM, after which concentrations decreased gradually with distinct peaks during MCA and present time (Fig. 4). Preservation of diatom valves were very poor between $\sim 21$ and $8.5 \mathrm{mcd}$, however the heavily silicified resting spores were 385 still found in some of the sediment samples in this section, but concentrations were relatively low. Due to possible dissolution, reconstructed concentrations might not be accurate in this section. During the MCA age, resting spore concentrations increased to ca. 185 million at ca. 5.5 mcd, following which 
concentrations decreased again. The most recently deposited sediments

390 revealed a pronounced increase in Chaetoceros sp. resting spore concentration ( 146 million/gdw). The high spore concentration in the recently deposited sediments is only comparable to the concentrations found during the HTM and MCA in our record.

395 Germination of recent and millennia old resting spores

We revived resting spores from the three time periods; (0-80 years (last century), 1300-1000 cal yr BP (MCA) and 7200-6000 cal yr BP (HTM). The environmental conditions were recreated to germinate the resting spores from the three ages which included reconstructing the salinity and temperature 400 conditions. The germination of Chaetoceros muelleri was observed to be consistent and dominant at temperatures ranging from $15-18^{\circ} \mathrm{C}$ and at a salinity of $(\sim 10.5-11)$ (Fig. 5A). On an average the time taken for the resting spores to germinate ranged from three hours to 2 -3 days.

405 Germination rate and viability of recent and millenia old resting spores The number of resting spores which germinated from the three time periods (080 years (last century), 1300-1000 cal yr BP (MCA) and $\sim 7200-6000$ cal yr BP (HTM) varied. A greater number of the younger $(\sim 0-80$ calendar years and 1300-1000 cal. yr BP) resting spores germinated as compared to the oldest 410 ( 7200-6000 cal yr BP) resting spores. On an average, the percent germination rate of the recent resting spores were the highest at $41 \pm 8.7$ (mean $\pm S E, n=$ 22) while the germination rate of the resting spores of the MCA and HTM ages were $31 \pm 8.9$ (mean $\pm S E, n=12$ ) and $12 \pm 6.7$ (mean $\pm S E, n=5$ ), respectively (Fig. 5B). A significant difference in the germination rate of the 415 recent and ancient spores $(P=0.0006, \mathrm{~F}=9.22)$ was found.

Physiology and reproduction of the recent and millenia old resting spores The resting spores isolated from the last century ( 0 - 80 years) reproduced and could be grown in culture but the old spores $(\sim 1300-1000$ and $\sim 7200-6000$ cal $420 \mathrm{yr}$ BP) of the MCA and HTM age germinated but could not be grown in cultures. The time taken for the recent and ancient spores were the same ranging from three hours to 2 to 3 days, but the germination rate (\%) of the ancient spores decreased with increasing time (see section on germination rate) (Fig. 5B). 
Identification of the Chaetoceros species

425 We identified the germinated Chaetoceros resting spores that we were able to culture as Chaetoceros muelleri Lemmermann (Fig. 6). Chaetoceros muelleri unlike other Chaetoceros taxa is a solitary living species with their vegetative cells characterized by a convex or flat valve surface (Fig. 2A-H), and their resting spores smooth with one valve bowed and the other protruded and 430 truncated (Johansen and Rushforth1985). The above characteristics also fit with the resting spores found in the culture (Fig. 2 A-H). The taxa has been reported from brackish waters in Europe and North America (Johansen and Rushforth 1985; Guiry 2017). In the checklist of Baltic Sea Phytoplanktic species; C. muelleri is recorded in nearly all subareas and considered a warm 435 water species found in low salinity and mainly eutrophic waters (Hällfors 2004).

Extraction and amplification of DNA from unialgal cultures of recent resting spores

We extracted high quality DNA with concentrations ranging from $\sim 100$ to $440235 \mathrm{ng} / \mathrm{ul}$ with a A260/A280 ratio of $\sim 1.7$ to 2 from the cultures of the germinated resting spores of the last century ( $\sim 0$ - 80 years). We amplified six primer pair combinations from rRNA (SSU) molecules and chloroplast genes $(r b c L)$ from three unialgal cultures (Tables 3).

445 Extraction and amplification of DNA from germinated single cells of millenia old resting spores

Single cell Chelex ${ }^{\circledR}$ DNA extraction on the older spores $(\sim 1300-1000$ cal yr (MCA age)) with a A260/A280 ratio of $\sim 1.7$ to 2 was done. DNA amplification was done using chloroplast (rbcL) and rRNA (SSU) markers.

Sanger sequencing of DNA from unialgal cultures of recent resting spores Partial sequences for chloroplast genes, $\mathrm{rbcL}(\sim 403-980 \mathrm{bp})$ and rRNA molecules, SSU (406-550 bp) were obtained by Sanger sequencing for three sediment revived resting spore populations of Chaetoceros (Fig. 6), the 455 sequences for the remaining genes were not obtained (Table 3). Sequence alignment and blast results of the nuclear ribosomal RNA (small subunit [SSU]) confirmed that the sequences were from the Chaetoceros species. Blast searches using the new sequences resulted in matches consistent with the 
genus-level morphological identifications of our specimens. Our validation of

460 methods in three unilalgal cultures showed no differences in the overall sequences and alignments.

\section{Discussion}

This study demonstrated the (i) successful germination and the germination

465 rate of recent ( $\sim 0-80$ years) and ancient resting spores $(\sim 7200-1000$ cal yrs BP) (Figs. 5A-B) (ii) DNA extraction and amplification from unialgal cultures of the recent spores ( $\sim 0-80$ years) and the single cells of millennia old $(\sim 1300$ 1000 cal yr BP) sediment revived resting spores (iii) DNA sequences from unialgal cultures of the recent spores (Fig. 6), and (iv) a method to identify the

470 species (Chaetoceros muelleri) from the morphology of viable germinated resting spores (Fig. 2) useful in the fields of microevolutionary, micropaleontology and paleoecology studies.

By reviving resting spores deposited in sediments and extracting DNA from

475 them we have demonstrated that Chaetoceros muelleri resting spores provide a promising model system for understanding species adaption and evolution across geological timescales and address questions about the impact of human-induced perturbations on life on Earth. Furthermore, previous attempts to use resting spores for paleoenvironmental reconstructions by assigning them

480 to species met with limited success as most of the resting spores are hard to classify (Ishii et al. 2011; Witak et al. 2011), severely hindering our understanding of paleoproductivity and the effect of environmental change on species. We revived several Chaetoceros species but we cultured only $C$. muelleri in this study. Resting cells of diatoms are virtually identical to

485 vegetative frustules in thickness as well as shape and pattern (McQuoid and Hobson, 1996). Previous studies on the diatom Skeletonema have shown that the morphology of the resting cells and germinated cells is indistinguishable (Itakura et al. 1992), whereas the resting and germinated spores of Chaetoceros species can be distinguished based on morphology. Therefore, the 490 ability to identify Chaetoceros species from the morphology of viable germinated recent and ancient resting spores of Chaetoceros will improve the scope of paleoecological studies (Witak et al. 2011). 
To the best of our knowledge this is the first study reviving thousands of years 495 old ( 7200-1000 cal yr BP) diatoms from dated sediments. Previous studies on the diatom Skeletonema marinoi showed that the sediments were dated to be a century old (Härnström et al. 2011). Other studies on the persistence of diatoms in marine sediments have reported germination of viable resting stages from sediment layers $\sim 30-40 \mathrm{~cm}$ below the sediment surface which

500 were estimated to be 175-275 years old (based on the sedimentation rates of 1.2-1.5 mm per year) (Stockner and Lund 1970).

Interestingly, our results indicate a different germination rate compared to the diatom species Skeletonema marinoi. The germination of resting spores of

505 Skeletonema marinoi from sediment layers older than a few decades can take weeks to months (Härnström et al. 2011) while the recent and ancient Chaetoceros muelleri spores in this study germinated in three hours to two to three days, which is a surprising and promising result. However, it was observed that although the time (three hours to 2-3 days) taken for the recent

510 and ancient resting spores to germinate remains the same the germination rate (\% of germination) of the ancient spores decrease with increasing time (Fig. 5B). We also found that the older spores ( 1000-1300 cal yrs BP) could be germinated but could not be grown in cultures. It is possible that the older spores had the ability to survive but were unable to reproduce. The lower

515 metabolic activity in the ancient spores indicates towards a trade-off between the longevity and viability of the spores and reproductive ability of the spores. The germination rates did vary significantly $(P=0.0006)$ between the different ages (Fig. 4B), which also suggests that just to remain viable over thousands of years has been a challenge for the species. The anoxic condition in the

520 Landsort Deep possibly reduced their metabolic activity through time and helped in preserving the spores (Fig. 4). Also, it's possible that the genetic and hence the physiological changes due to climatic or environmental changes over a thousand years could have affected its ability to reproduce.

525 The successful DNA extraction and amplification from unialgal cultures of the recent spores ( 0-80 years) and DNA extraction of the single cells of millennia old ( 1300-1000 cal yr BP) sediment revived resting spores reveals that the DNA in the sediment revived resting spores are well-preserved and hence 
presents itself as an excellent model system for tracing the evolutionary history

530 of species. The amplification and Sanger sequencing of the plastid-encoded rbcL ( 403- 980 bp) and nuclear-encoded SSU rRNA gene (406-550 bp) from the cultures show the possibilities for further studies. The non-existing variation within this genomic region was expected as this is a slow evolving region (Patwardhan et al. 2014) and was mainly used for species identification and

535 PCR-amplification control.

Previous studies especially in humans has revealed that despite treatment of the laboratory equipment with bleach, UV irradiation of the entire facility, protective clothing and face shields and other routine precautions,

540 contamination is a continuous threat, if for no other reason than because the specimens themselves might be contaminated with modern DNA (Hofreiter et al., 2001). Hence, the availability of high quality DNA from sediment revived recent and ancient spores in a system so well preserved where the chances of contamination are minimal as opposed to systems like humans is like a dream

545 come true and provides immense potential for future microevolutionary studies. In this study precaution against contamination was taken in every step from sampling to PCR, by using perfluorocarbon added in the liner fluid to trace possible contamination when sampling the long cores and no contamination was detected. These cores were carefully subsampled by the curators at IODP

550 Core Repository in Bremen and single spores were isolated with care following the protocol of Throndsen (1978). For the DNA extraction and amplification care was taken to avoid contamination; preparations were conducted in PCR-free environment.

555 The findings of this study reveal the potential of identifying more markers, assembling a complete genome, making comparisons of populations across temporal and spatial scales genetically with sediment revived recent and ancient spores but also experimentally with recent spores. Adequate comprehensive studies of population genetic structure in phytoplanktic species

560 along environmental gradients like salinity combined with experimental data are lacking and the results in this study creates this opportunity. A previous study has shown that Baltic Sea populations displayed reduced genetic diversity compared to North Sea populations. The study also showed significant 
differences in the growth of low and high native salinity isolates indicating local

565 salinity adaptation (Sjöqvist et al. 2015). Here we show that it will be possible to examine the genetic diversity and evolutionary changes in Chaetoceros populations across evolutionary timescales: $\sim 80$ years (last century), 13001000 cal yr BP (MCA) and 7200-6000 cal yr BP (HTM) from sediments drilled in the Landsort Deep. Future studies can include identification of genetic

570 markers and differences in gene expression levels to determine the changes in the population genetic structure across environmental gradients over time in sediment revived Chaetoceros populations. Population genomics studies using DNA data obtained from modern DNA technologies and single cell genomics together can be used to understand the evolutionary changes in the species

575 due to natural environmental change and/or climate change or anthropogenic effects and to gain insights into the mechanisms of molecular evolution.

In conclusion, this study presents a new model system using Chaetoceros muelleri to address the important topic of adaptive evolution in marine species

580 due to climate and environmental change induced by anthropogenic perturbations across evolutionary timescales. Our study reports (1) the revival, viability and germination rate of recent (0-80 years) to ancient ( $\sim 7200-\sim 1000$ calendar years BP old) resting spores of Chaetoceros muelleri (2) the extraction of DNA and amplification of chloroplast and ribosomal genes from recent spores

585 and DNA extraction from ancient resting spores of C. muelleri (3) Radiocarbon dating along with stratigraphic time markers to determine age of sediments (4) Identification of the species by reviving the resting spores (5) Baltic Sea an excellent ecosystem to study long-term effects of environment on species adaptation.

\section{Acknowledgement}

We thank the captain and crew of R/V Greatship Manisha and M/S Fyrbyggaren, as well as the IODP Expedition 347 science party. Part of the sediment samples for this study were provided by IODP. We also thank Dr. Lubna Elabbas for 595 assistance in the lab and Asst. Prof. Sunčica Bosak, University of Zagreb for help with species identification of Chaetoceros muelleri. Prof. Martin Jakobsson at Stockholm University generously made the Baltic Sea map available for our use. 
600 References

Andersen, J.H., J. Cartensen, D. J. Conley, K. Dromph, V. Fleming-Lehtinen, B. G. Gustafsson, et al. 2017. Long-term temporal and spatial trends in eutrophication status of the Baltic Sea. Biological Reviews 92: 135-149.

Andrén, E., T. Andrén, and H. Kunzendorf. 2000. Holocene history of the Baltic

605 Sea as a background for assessing records of human impact in the sediments of the Gotland Basin. The Holocene 10: 687-702.

Andrén, E., G. Shimmield, and T. Brand. 1999. Changes in the environment during the last centuries on the basis of siliceous microfossil records from the southwestern Baltic Sea. The Holocene 9: 25-38.

610 Andrén, T., S. Björck, E. Andrén, D.J. Conley, L. Zillén, and J. Anjar. 2011. The development of the Baltic Sea basin during the last $130 \mathrm{ka}$. In: Harff J, Björck S, Hoth P (eds) The Baltic Sea basin. Springer, Berlin, pp 75-97.

Andrén, T., B.B. Jørgensen, C. Cotterill, and S. Green. 2015. the Expedition 347 Scientists Proceedings IODP 347: College Station, TX (Integrated Ocean Drilling

615 Program). doi:10.2204/iodp.proc.347.107.2015.

Battarbee, R. W. 1986. Diatom analysis. In BE Berglund (Ed.), Handbook of Holocene palaeoecology and palaeohydrology. Chichester: Wiley.

Battarbee, R.W, and M. J. Kneen. 1982. The use of electronically counted microspheres in absolute diatom analysis. Limnology and Oceanography 27:

620 184-188.

Blaauw, M. 2010. Methods and code for 'classical' age-modelling of radiocarbon sequences. Quaternary Geochronology 5: 512-518.

Bu, Z-J., S. Sundberg, L. Feng, H-K Li, H-Y Zhao, H-C Li. 2017. The Methusaleh of plant diaspores: Sphagnum spores can survive in nature for centuries. New 625 Phytologist 214: 1398-1402.

Burge, D.R.L., M. B. Edlund, and D. Frisch. 2017. Paleolimnology and resurrection ecology: The future of reconstructing the past. Evolutionary Applications 11: 42-59.

Cáceres, C. E., and N. G. Hairston. Jr. 1998. Benthic-pelagic coupling in 630 planktonic crustaceans: The role of the benthos. Ergebnisseder Limnologie 52: 163-174. 
Carstensen, J., J. H. Andersen, B. G. Gustafsson, and D. J. Conley. 2014. Deoxygenation of the Baltic Sea during the last century. Proceedings of the National Academy of Sciences of the United States of America 111: 5628-5633.

635 Cleve-Euler, A. 1951. Die Diatomeen von Schweden und Finnland. Kungliga Vetenskapsakademiens Handlingar 4:e serien 2:1, 163 pp.

Crosta, X., J. J. Pichon, and M. Labracherie. 1997. Distribution of Chaetoceros resting spores in modern peri-Antarctic sediments. Marine Micropaleontology 29: 283-299.

640 Ellegaard, M, and S. Ribeiro. 2017. The long-term persistence of phytoplankton resting stages in aquatic 'seed banks'. Biological Reviews doi: $10.1111 /$ brv.12338.

Guiry. M. D. 2017. In Guiry MD, Guiry GM. AlgaeBase. World-wide electronic publication, National University of Ireland, Galway. http://www.algaebase.org;

645 searched on 26 June.

Gustafsson, B. G., and P. Westman. 2002. On the causes for salinity variations in the Baltic Sea for the last 8500 years. Paleoceanography 17: 1-14.

Hällfors. G. 2004. Checklist of Baltic Sea Phytoplankton Species (including some heterotrophic protistan groups). BSEP 95: 208 pp.

650 Härnström, K, M. Ellegaard, T. J. Andersen, and A. Godhe. 2011. Hundred years of genetic

structure in a sediment revived diatom populations. Proceedings of the National Academy of

Sciences of the United States of America 108: 4252-4257.

655 Hofman, C. A., T. C. Rick, R. C. Fleischer, and J .E. Maldano. 2015. Conservation archaeogenomics: ancient DNA and biodiversity in the Anthropocene. Trends in Ecology \& Evolution 30: 540-549.

Hofreiter, M., D. Serre, H. N. Poinar, M. Kuch, and S. Pääbo. 2001. Ancient DNA. Nature Reviews 2: 353-359.

660 Ishii K-I., M. Iwataki, K. Matsuoka, and Imai I. 2011. Proposal of identification criteria for resting spores of Chaetoceros species (Bacillariophyceae) from a temperate coastal sea. Phycologia 50: 351-362.

Itakura, S., I. Imai, and K. Itoh. 1992. Morphology and rejuvenation of Skeletonema costatum (Bacillariophyceae) resting cells from the bottom 665 sediments of Hiroshima bay, the Seto inland sea, Japan. Bulletin of Plankton Society of Japan 38: No. 2. pp. 135-145. 
Johansen, J. R., and S.R. Rushforth. 1985. A contribution to the taxonomy of Chaetoceros muelleri Lemmermann (Bacillariophyceae) and related taxa. Phycologia 24: 437-447.

670 Kitchell, J.A., D.L. Clark, and A. M. Gombos Jr. 1986. Biological Selectivity of Extinction: A Link between Background and Mass Extinction. PALAIOS 1: 504511.

Krammer, K., and H. Lange-Bertalot. 1991. Bacillariophyceae, 3. Teil Centrales, Fragilariaceae, Eunotiaceae. In: Ettl, H., Gerloff, J., Heynig, H. and Mollenhauer,

D. (Eds) Süsswasserflora von Mitteleuropa. Gustav Fischer Verlag, Stuttgart. $576 \mathrm{pp}$.

Larsson, J., M. Lönn, E. E. Lind, J. Swiezak, K. Smolarz, and M. Grahn. 2016. Sewage treatment plant associated genetic differentiation in the blue mussel from the Baltic Sea and Swedish west coast. Peer] 4: e2628.

680 Lee, M-A., D. G. Faria, M-S. Han, J. Lee, J-S. Ki. 2013. Evaluation of nuclear ribosomal RNA and chloroplast gene markers for the DNA taxonomy of centric diatoms. Biochemical Systematics and Ecology 50: 163-174.

Malviya S., E. Scalco, S. Audic, F. Vincent, A. Veluchamy, J Poulain, et al. 2016. Insights into global diatom distribution and diversity in the world's ocean.

685 Proceedings of the National. Academy of Sciences of the United States of America 113: E1516 - E1525.

Mann, M.E. Z. Zhang, S. Rutherford, R. S. Bradley, M. K. Hughes, D. Shindell, et al. 2009. Global signatures and dynamical origins of the Little Ice Age and Medieval Climate Anomaly. Science 326: 1256-1260.

690 McQuoid MR, Hobson LA. 1996. Diatom resting stages. Journal of Phycology 32: 889-902.

Miyazono, A., S. Nagai, I. Kudo, K. Tanizawa. 2012. Viability of Alexandrium tamarense cysts in the sediment of Funka Bay, Hokkaido, Japan: Over a hundred year survival times for cysts. Harmful Algae 16, 81-88.

695 Moros, M., T. J. Andersen, D. Schulz-Bull, K. Häusler, D. Bunke, I. Snowball, et al. 2017. Towards an event stratigraphy for Baltic Sea sediments deposited since AD 1900: approaches and challenges. Boreas 46: 129-142.

Obrochta, S.P. T. Andrén, S. Z. Fazekas, B. C. Lougheed, I. Snowball, Y. Yokoyama, et al. 2017. The undatables: Quantifying uncertainty in a highly 700 expanded Late Glacial-Holocene sediment sequence recovered from the 
deepest Baltic Sea basin-IODP Site M0063. Geochemistry Geophysics Geosystems 18: 858-872.

Orsini, L., K. Schwenk, L. De Meester, J. K. Colbourne, M. E. Pfrender, and L. J. Weider. 2013. The evolutionary time machine: Forecasting how populations can

705 adapt to changing environments using dormant propagules. Trends in Ecology \& Evolution 28: 274-282.

Patwardhan, A., S. Ray, and A. Roy. 2014. Molecular Markers in Phylogenetic Studies-A Review J Phylogenetics Evol Biol 2(2): 131.

Reimer, P.J., E Bard, A. Bayliss, and J. W. Beck. 2013. IntCal13 and Marine13

710 radiocarbon age calibration curves, 0-50,000 years cal BP. Radiocarbon 55: 1869-1887.

R Core Team. (2014). R: A language and environment for statistical computing. R Foundation for Statistical Computing, Vienna, Austria. URL http://www.Rproject.org/.

715 Schlüter, L. K. T. Lohbeck, M. A. Gutowska, J. P. Gröger, U. Riebesell, and T. B. H. Reusch. 2014. Adaptation of a globally important coccolithophore to ocean warming and acidification. Nature Climate Change 4: 1024-1030.

Seppä, H., A. E. Bjune, R. J. Telford, H. J. B Birks, and S. Veski. 2009. Last ninethousand years of temperature variability in Northern Europe. Climate of the

720 Past 5: 523-535.

Sjöqvist, C., A. Godhe, P. R. Jonsson, L. Sundqvist, A. Kremp. 2015. Local adaptation and oceanographic connectivity patterns explain genetic differentiation of a marine diatom across the North Sea Baltic Sea salinity gradient. Molecular Ecology 24:_2871-2885.

725 Snoeijs-Leijonmalm, P., and E. Andrén. 2017. Why is the Baltic Sea so special for organisms to live in? Biological Oceanography of the Baltic Sea. In: SnoeijsLeijonmalm, P., Schubert, H. \& Radziejewska, T. (eds). Springer, Dordrecht, 23$84 \mathrm{pp}$.

Stockner, J.G., and J.W.G. Lund. 1970. Live algae in postglacial sediments.

730 Limnology and Oceanography 15: 41-58.

Throndsen, J. 1978. Preservation and storage. In: Sournia A (ed) Phytoplankton manual. UNESCO, Paris, pp. 69-74.

Waters, C. N., J. Zalasiewicz, C. Summerhayes, A. D. Barnosky, C. Poirier, A. Gałuszka, et al. 2016. The Anthropocene is functionally and stratigraphically 
Whitehead, A. 2014. Evolutionary genomics of environmental pollution. In: Landry, Aubin-Horth, eds. Ecological Genomics. Netherlands: Springer, 321337.

Witak, M., J. Dunder, and M. Leśniewska. 2011. Chaetoceros resting spores as 740 indicators of Holocene paleoenvironmental changes in the Gulf of Gdańsk, southern Baltic Sea. Oceanological and Hydrobiological Studies 40: 21-29.

Yasuhara, M., G. Hunt, D. Breitburg, A. Tsujimoto, and K. Katsuki. 2012. Humaninduced marine ecological degradation: micropaleontological perspectives. Ecology and Evolution 2: 3242-3268.

745 Yousey, A.M., P. Roy Chowdhury, N. Biddinger, J. H. Shaw, P. D. Jeyasingh, and L. J. Weider. 2018. Resurrected 'ancient' Daphnia genotypes show reduced thermal stress tolerance compared to modern descendants. R Soc Open Sci 5(3); 172193.

Zillén, L., D. J. Conley, T. Andrén, E. Andrén, and S. Björck. 2008. Past

750 occurrences of hypoxia in the Baltic Sea and role of climate variability, environmental change and human impact. Earth-Science Reviews 91: 77-92.

Zuccarello, G.C., and G. M. Lokhorst. 2005. Molecular phylogeny of the genus Tribonema (Xanthophyceae) using rbc L gene sequence data: monophyly of morphologically simple algal species. Phycologia 44: 384-392. 


\section{Figure captions and legends.}

Fig. 1. Map showing the position of the investigated IODP Expedition 347 site

M0063 in the Landsort Deep (58 $\left.37.32^{\prime} \mathrm{N}, 18^{\circ} 15.24^{\prime} \mathrm{E}\right)$ where a ca $116 \mathrm{~m}$ long sediment core was drilled at a water depth of $437 \mathrm{~m}$ (Andrén et al. 2015). Baltic Sea has a long salinity gradient in the surface waters ranging from $\sim 12-30$ in Kattegatt, 10-23 in Danish straits (Ds), 8-11 in Arkona Basin, 5-7.5 in Baltic Proper and $\sim 2-4$ in Bothnian Bay (Andersen et al. 2017).

765

Fig 2. Light micrographs of Chaetoceros muelleri Lemmermann in the culture revived from the sediment at $10-11 \mathrm{~cm}$ depth. A-D. Vegetative cells in valve view (A-B Smooth solitary cell) and girdle view (C-D showing convex valve shape). Note that both vegetative cell and resting spore is visible in $\mathrm{D}$. E-H. Resting spores in girdle view showing various characteristic morphologies. Scale bar A-D 20 microns, E-H 5 microns.

Fig. 3. Stratigraphic time markers in cores M0063I (mercury - Hg) and M0063H ( $\mathrm{Hg}$ and artificial radionuclides ${ }^{137} \mathrm{Cs}$ and ${ }^{241} \mathrm{Am}$ ) following the approach described in Moros et al. (2017). Core correlation is based on $\mathrm{Hg}$ downcore profiles in M0063I (black) and M0063H (grey) which are shown versus respective core depths. In addition, total organic carbon (TOC, blue) and carbonate (light blue) data of $\mathrm{M0063 \textrm {H }}$ are shown. Hg (dark green) and ${ }^{137} \mathrm{Cs}$ (black, right) are normalized to TOC as the manganese-carbonate layers dilute

780 the signals. Horizontal dashed red line marks an age of c. AD 1940 which can be assigned to this depth.

Fig. 4. Lithology and Chaetoceros spp. resting spore concentrations (million valves per gram dry sediment) in the upper 30 meter sediments of IODP Exp.

785347 hole M0063D (Landsort Deep). The high concentrations of MCA and HTM ages are recorded in laminated organic rich clays (equals to hypoxic bottom water conditions).

Fig. 5. (A) Germination of resting spores of Chaetoceros sp. (B) Germination 790 rate of the resting spores from the three ages. 
Fig. 6. Sequences and alignment of the rbcL and SSU rDNA of Chaetoceros muelleri.

\section{Tables.}

Table 1. AMS radiocarbon dates and calibrated ages of bulk sediment samples from Expedition 347, site M0063, hole C and D.

\begin{tabular}{|c|c|c|c|c|c|c|c|c|}
\hline $\begin{array}{l}\text { Laboratory } \\
\text { ID }\end{array}$ & Site and hole & Sample ID IODP & Depth (mcd) & ${ }^{14} \mathrm{C}$ Age & Error & $\begin{array}{l}\text { Calibrate } \\
\text { range }\end{array}$ & d age & 2 sigma \\
\hline & & & & & & median & $\min$ & $\max$ \\
\hline Core top & & & 0 & & & -63 & & \\
\hline Beta 418207 & M0063C & $347-25772$ & 5.22 & 1760 & 30 & 962 & 577 & 1373 \\
\hline Beta 418209 & M0063C & $347-25774$ & 6.22 & 1900 & 30 & 1301 & 872 & 1768 \\
\hline Beta 418041 & M0063D & 347-28991 & 15.65 & 4590 & 30 & 4385 & 3690 & 4966 \\
\hline Beta 418042 & M0063D & $347-29274$ & 17.29 & 5120 & 30 & 5077 & 4533 & 5578 \\
\hline Beta 418043 & M0063D & $347-29319$ & 20.13 & 5480 & 30 & 5612 & 5066 & 6154 \\
\hline Beta 418046 & M0063D & $347-30771$ & 27.45 & 7380 & 30 & 7604 & 7040 & 8099 \\
\hline
\end{tabular}
800

Table 2. Calibrated ages modelled for the diatom samples analyzed of MCD and HTM age.

\begin{tabular}{|c|c|c|c|c|c|c|}
\hline \multirow[t]{2}{*}{ Site and hole } & \multirow{2}{*}{\multicolumn{2}{|c|}{$\begin{array}{l}\text { Sample } \\
\text { IODP }\end{array}$}} & \multirow[t]{2}{*}{$\begin{array}{l}\text { Depth } \\
\text { mcd }\end{array}$} & \multicolumn{2}{|c|}{$\begin{array}{l}\text { Calibrated age } \\
\text { range }\end{array}$} & \multirow{2}{*}{$\begin{array}{l}\text { sigma } \\
\max \\
\end{array}$} \\
\hline & & & & median & $\min$ & \\
\hline M0063C & $347-39293$ & & 5.42 & 1030 & 693 & 1416 \\
\hline M0063C & 347-39299 & & 6.02 & 1233 & 854 & 1641 \\
\hline M0063C & $347-39300$ & & 6.12 & 1267 & 864 & 1703 \\
\hline M0063C & $347-39301$ & & 6.22 & 1301 & 872 & 1768 \\
\hline M0063C & 347-39302 & & 6.32 & 1335 & 880 & 1833 \\
\hline M0063D & $347-29645$ & & 21.63 & 6022 & 5579 & 6459 \\
\hline M0063D & $347-29748$ & & 21.83 & 6076 & 5653 & 6499 \\
\hline M0063D & $347-29750$ & & 23.74 & 6595 & 6234 & 6950 \\
\hline M0063D & $347-30184$ & & 24.07 & 6685 & 6321 & 7035 \\
\hline M0063D & $347-30204$ & & 26.05 & 7223 & 6760 & 7640 \\
\hline
\end{tabular}


Table 3. Sequence results of rRNA (SSU) molecules and chloroplast genes ( $r b c L$ ) of three unialgal cultures.

$\begin{array}{llllll}\text { Unialgal culture } & \text { Marker } & \text { Orientation } & \text { Nucleotidea sequence } & \text { Target gene } \begin{array}{l}\text { Length } \\ (\mathrm{bp})\end{array} \\ 3 & \text { Dt-rbcL-F56 } & \text { Forward } & \text { AGTGACCGTTACGAATCTGG } & \text { rbcL } & 980 \\ 3 & \text { Dt-rbcL-R1010 } & \text { Reverse } & \text { AGGATCACCTCTAATTACC } & \text { rbcL } & 962 \\ 1 & \text { Cy18F150 } & \text { Forward } & \text { GCTAATACATGCATCAATACC } & \text { SSU } & 406 \\ 1 & 18 R 560 & \text { Reverse } & \text { GCTATTGAGCTGGAATACC } & \text { SSU } & 410 \\ 3 & \text { Cy18F150 } & \text { Forward } & \text { GCTAATACATGCATCAATACC } & \text { SSU } & 406 \\ 3 & \text { 18R560 } & \text { Reverse } & \text { GCTATTGAGCTGGAATACC } & \text { SSU } & 406 \\ 1 & \text { Dt18F150 } & \text { Forward } & \text { ATACCCGTAGTAATTCTAGAGC } & \text { SSU } & 550 \\ 1 & \text { 18R560 } & \text { Reverse } & \text { GCTATTGGAGCTGGAATACC } & \text { SSU } & 420 \\ 2 & \text { Dt18F150 } & \text { Forward } & \text { ATACCCGTAGTAATTCTAGAGC } & \text { SSU } & 545 \\ 2 & \text { 18R560 } & \text { Reverse } & \text { GCTATTGGAGCTGGAATACC } & \text { SSU } & 54\end{array}$




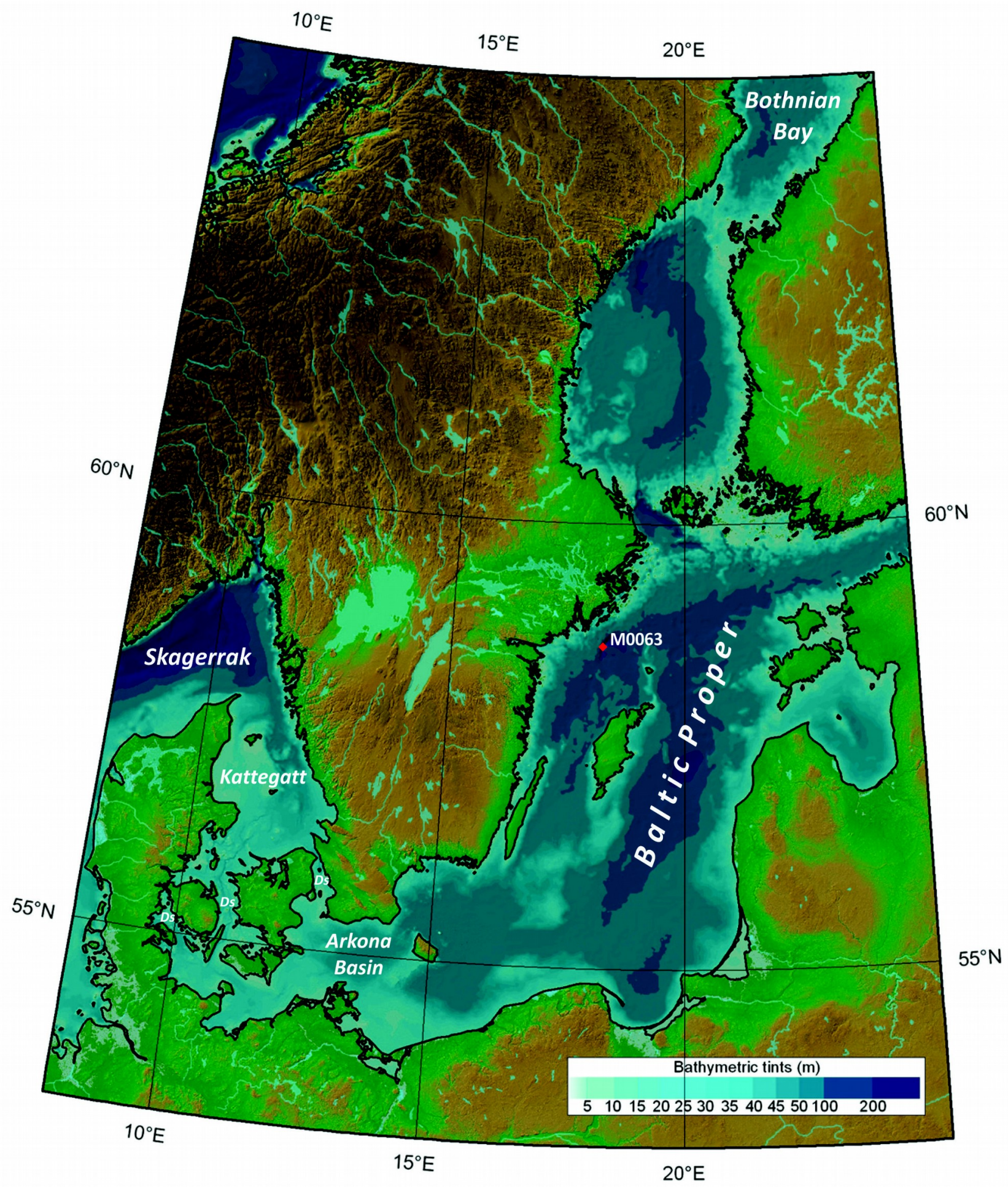

Fig. 1. 


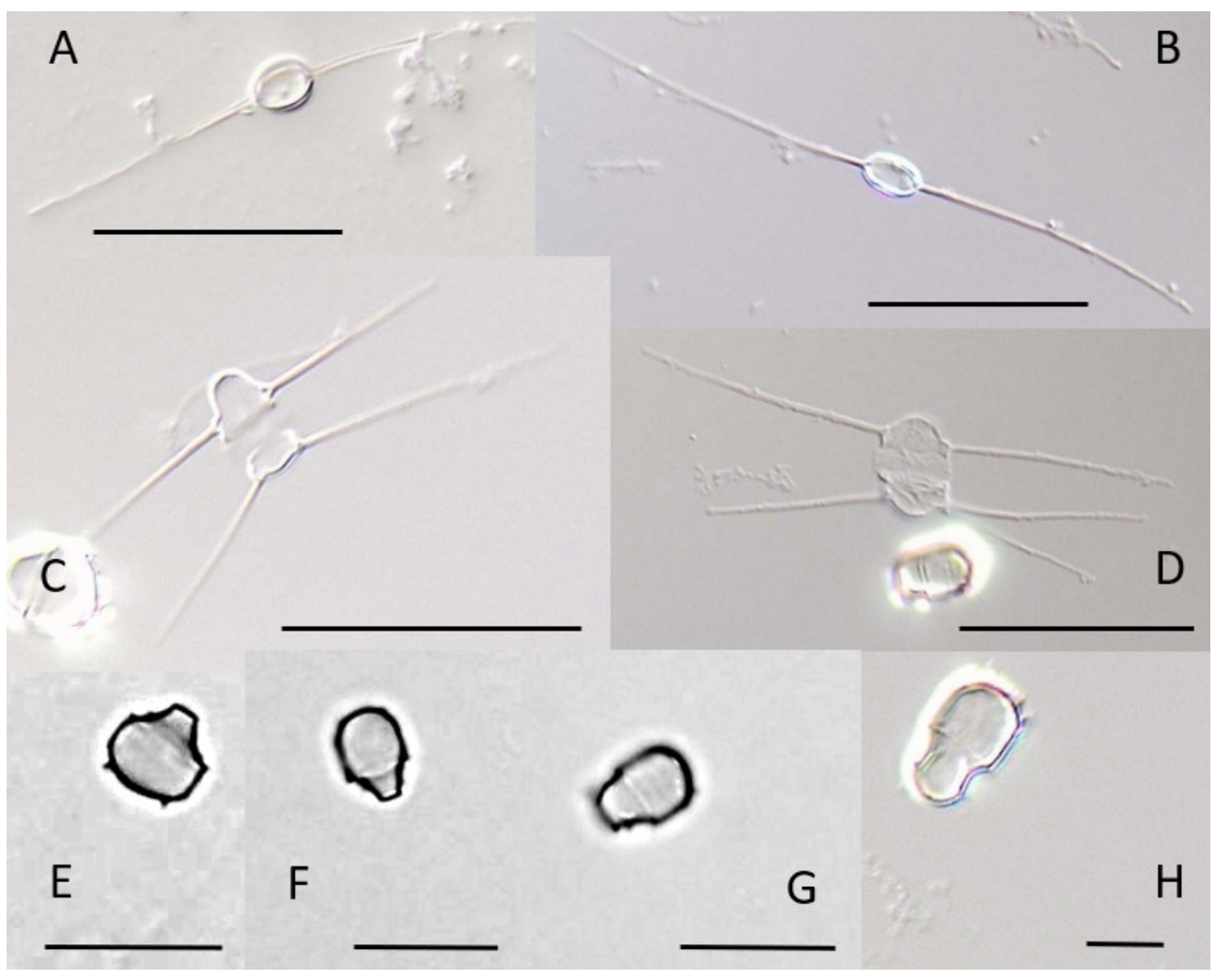

865

Fig. 2. 
885 Fig. 3.

$$
\mathrm{Hg}(\mu \mathrm{g} / \mathrm{kg}) \quad \mathrm{TOC}(\%) \quad{ }^{137} \mathrm{Cs}(\mathrm{Bq} / \mathrm{kg}) \quad \mathrm{Hg} / \mathrm{TOC}
$$

890

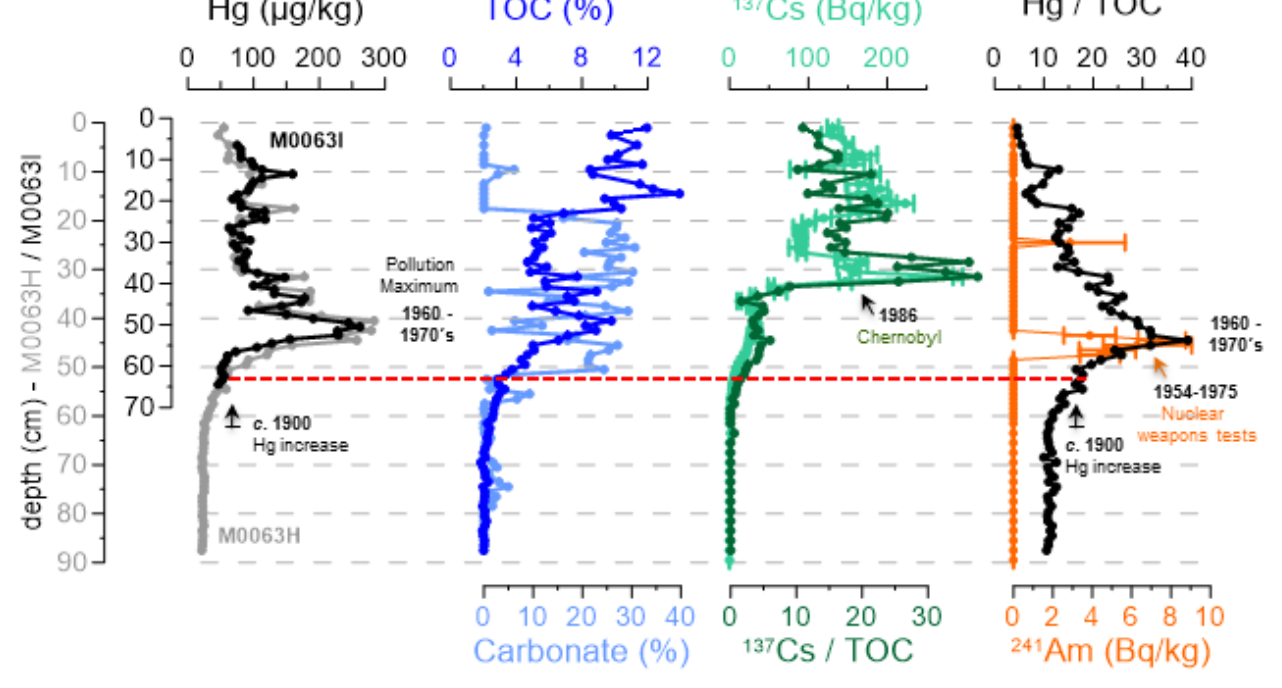

900

905 


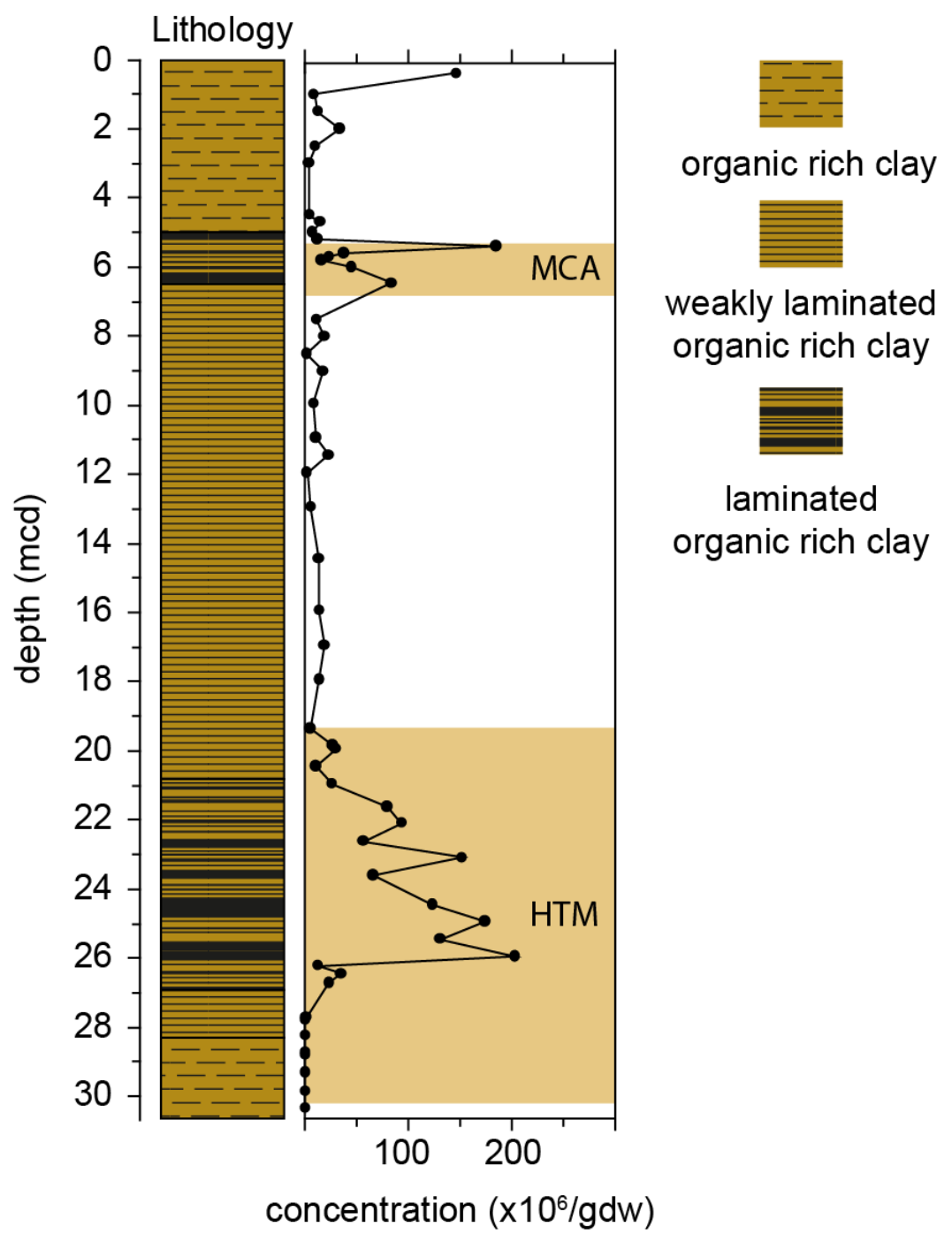

935 Fig. 4. 
A

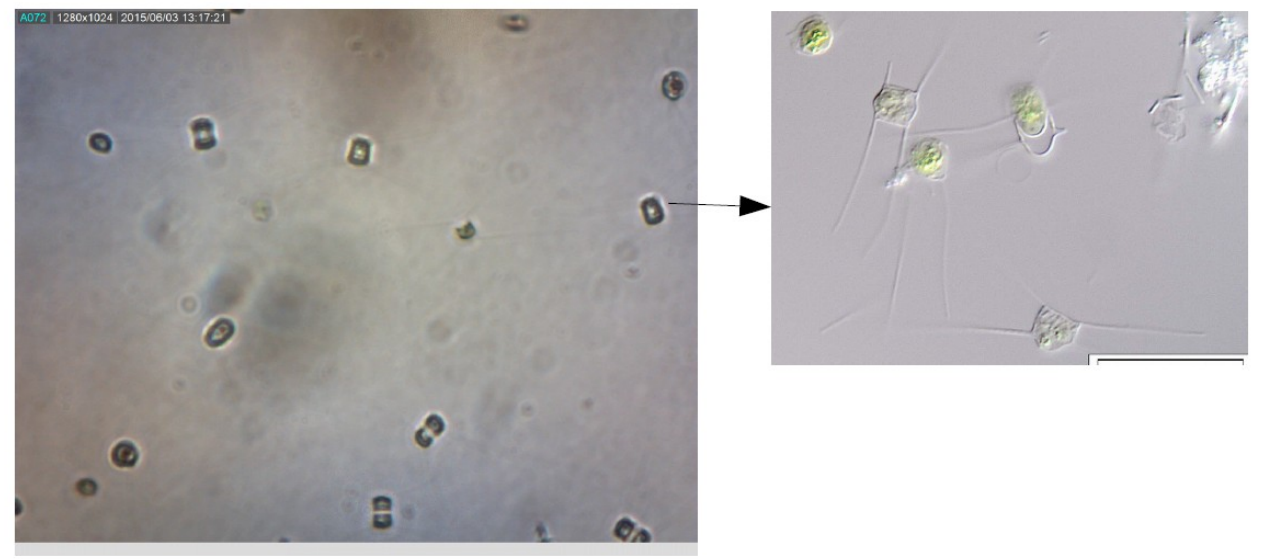

B

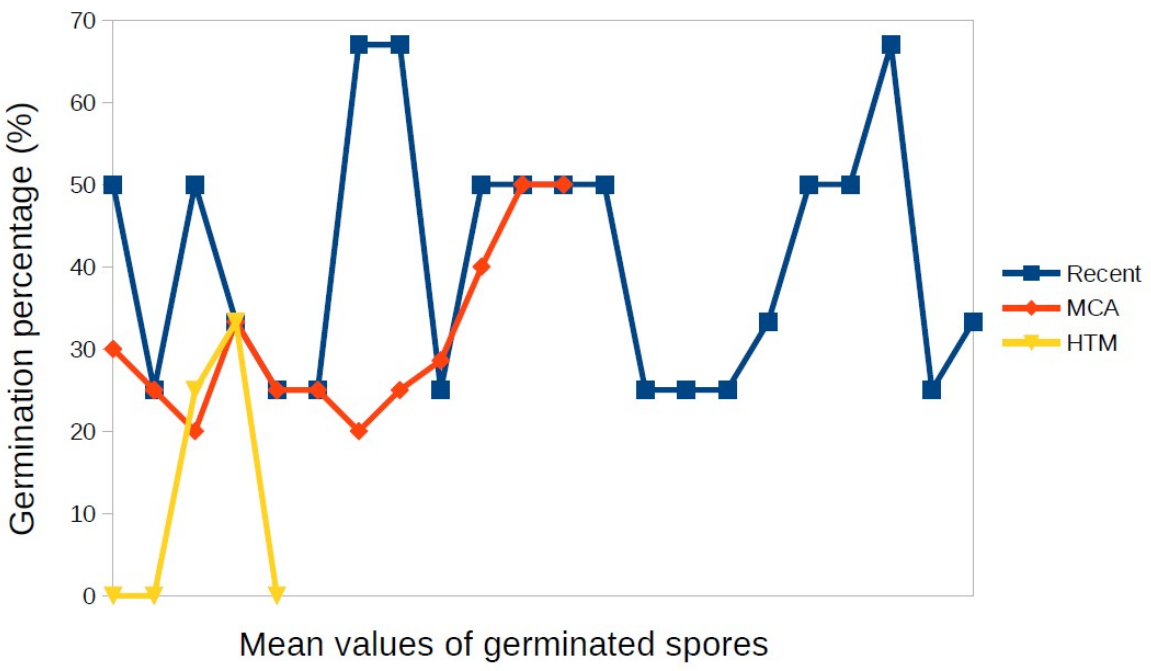

Fig. 5. 


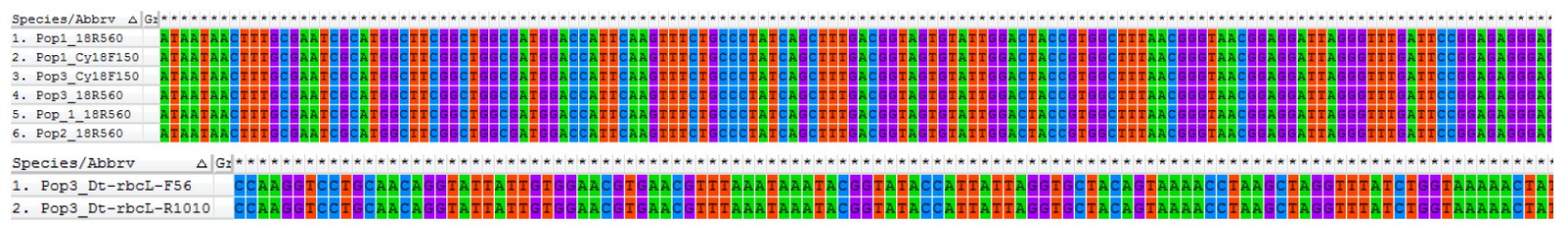

Fig. 6. 